\title{
RICE-FISH FARMING SYSTEM IN LAMONGAN, EAST JAVA, INDONESIA: SWOT AND PROFIT EFFICIENCY ANALYSIS
}

\author{
Dyah Retnani Nurhidayati ${ }^{1,2^{*}}$, Wen-Chi Huang ${ }^{2}$, Nuhfil Hanani $^{3}$, Sujarwo $^{3}$ \\ ${ }^{1}$ Double Degree Program in Faculty of Agriculture, Brawijaya University, Indonesia \\ ${ }^{2}$ National Pingtung University Science and Technology, Taiwan \\ ${ }^{3}$ Faculty of Agriculture, Brawijaya University, Indonesia \\ *corresponding author: dyahrn1995@gmail.com
}

\begin{abstract}
The agricultural sector needs to make breakthroughs in the design of production systems to improve farmers' income and operation efficiency. One of the ways is to redesign rice production methods by applying a rice-fish farming system. Lamongan has a different system that combines rice cultivation with vannamei shrimp. Due to the limitation of farmers, system's efficiency has not yet reached the optimal level. This study describes the rice-fish farming system, identifies the SWOT and generated the grand strategy matrix, and analyzed the profit efficiency using Stochastic Frontier Analysis. The results showed that the strengths and opportunities are more influential, where the position was in the quadrant I; which means it is in a good strategic position. Meanwhile, the input factors that significantly influence profit are the cost of paddy seed, the cost of organic fertilizer, the cost of inorganic fertilizer, the cost of pesticide, and the cost of shrimp feed. The profit efficiency analysis shows that respondents engaged in this system did not efficiently allocate inputs and production cost factors appropriately. The average profit efficiency level was 78.05 percent; it means that there were still opportunities to increase profits from the system by 21.5 percent.
\end{abstract}

Keywords: Rice-fish farming, profit efficiency, stochastic frontier, SWOT.

http://dx.doi.org/10.21776/ub.agrise.2020.020.4.6

Received 17 July 2020

Accepted 20 October 2020

Available online 30 October 2020

\section{INTRODUCTION}

Most of the Indonesian farmers are subsistence (Raharjo, 2014), especially rice farmers who cultivate only to fulfill their daily needs due to limited knowledge, modern technology and lack of agricultural land owned. This causes low income of farmers. Therefore, the agricultural sector required to make breakthroughs. One way to optimize the potential of land and increase farmers' income is to engineer land with appropriate technology (Sudiarta et al., 2016). The way that can be done is to change the agricultural strategy from the monoculture system to the agricultural diversification system by applying the rice-fish farming system (Hikmasari et al., 2013). Shefat et al. (2018), also mentioned that single crop production system is vulnerable to various risks and uncertainties, such as seasonal, intermittent, income and job uncertainties, for farmers who have called for the implementation of an effective integrated farming system. Rice-fish farming can play an important role in raising the income and food production of households (Ahmed et al., 2011). This system is an agricultural activity that combines fish farming with rice cultivation in rice fields (Akbar, 2017). This system is better than rice monoculture in terms of resource use, crop abundance, farm efficiency or economy, and both the quality and quantity of the food products (Rahman, 2016).

Rice-fish farming should be applied, because it produces two outputs or two harvests, namely harvesting rice and harvesting fish, resulting in higher income (Hikmasari et al., 2013). Besides, rice-fish farming also has the advantages of being complementary (Simon \& Benhamou, 2009). If there is a failure in harvesting rice, farmers still have the results of harvesting fish that can cover losses of rice farming.

Lamongan is one of the districts in Indonesia that use the rice-fish farming system. The cultivation system used in Lamongan is different from the rice-fish farming system that is carried out elsewhere in Indonesia, where rice-fish farming usually combines rice cultivation with tilapia but in Lamongan rice cultivation is carried out together with shrimp culture. Although, the shrimp live in the sea naturally, shrimp has euryhaline properties, which can live in water with a wide range of salt levels. This means that shrimp can live in saltwater, brackish water, 
and freshwater (Sudradjat \& Wedjatmiko, 2010). Meanwhile, rice fields in Lamongan are brackish, so that it strongly supports rice cultivation with shrimp.

On the other hand, the production of rice-fish farming system is not optimal due to the level of farmer's education and knowledge in allocating different production factors and operational skills of the farmers that are not optimal (Oladimeji \& Z. Abdulsalam, 2013). The way to find out what needs to be improved and what strategies are needed in this cultivation system is by analyzing the strengths, weaknesses, opportunity, and threat that the system has and calculating profit efficiency that can measure the ability of rice-fish farmers to minimize costs and optimize profits. Other researchers in Lamongan have never done this study of rice-fish farming. SWOT analyzes the strengths, weaknesses, opportunities, and threats of any technology that helps the decision-makers to determine whether or not the goals are achievable (Shefat et al., 2018). This research is expected to be used as consideration in overcoming the problems of rice-fish farming production in Lamongan and is one of the bases in making decisions to increase the income of rice farmers in Indonesia.

\section{RESEARCH METHOD}

This study used secondary data and primary data. Secondary data were obtained from the agricultural service in Lamongan, including data on rice-fish farming farmers, land area, and fertilizer requirements of each farmer in the last planting season. The primary data was obtained by conducting interviews with 221 respondents of rice-fish farming farmers using a questionnaire.

The methods used in this research are SWOT analysis and Stochastic Frontier Analysis. SWOT analysis is done by calculating the score of each factor there are Strengths, Weaknesses, Opportunities, threats. Whereas to analyze profit efficiency is using Frontier 4.1 application, further SFA analysis used by researchers is as the following frontier profit function specified.

Production factors used in rice-fish farming systems and allegedly influence the profit of rice-fish production in Lamongan, East Java, Indonesia are the cost of paddy seed, cost of shrimp seed, labor wage, cost of organic fertilizer, cost of inorganic fertilizer, cost of pesticide, and cost of shrimp feed. The systematic function of rice-fish farming in Lamongan can be written as follows:

$Y=\beta_{0}+\beta_{1} X_{1}+\beta_{2} X_{2}+\beta_{3} X_{3}+\beta_{4} X_{4}+\beta_{5} X_{5}+\beta_{6} X_{6}+\beta_{7} X_{7}+v i-$

ui ................................................(1)

The function needs to be transformed in the form of a linear natural econometric logarithm, so its function is defined as:

Ln $Y=\beta_{0}+\beta_{1} \ln X_{1}+\beta_{2} \ln X_{2}+\beta_{3} \ln X_{3}+\beta_{4} \ln X_{4}+\beta_{5} \ln X_{5}+$ $\beta_{6} \ln X_{6}+\beta_{7} \ln X_{7}+$ vi-ui.

Where :

$\mathrm{Y}=$ normalized profit computed for each farmer

$\mathrm{X}_{1}=$ Cost of paddy seed $(\mathrm{Rp} / \mathrm{Ha})$

$\mathrm{X}_{2}=$ Cost of shrimp seed $(\mathrm{Rp} / \mathrm{Ha})$

$\mathrm{X}_{3}=$ Labor wage $(\mathrm{Rp} / \mathrm{Ha})$
$\mathrm{X}_{4}=$ Cost of organic fertilizer $(\mathrm{Rp} / \mathrm{Ha})$

$\mathrm{X}_{5}=$ Cost of inorganic fertilizer $(\mathrm{Rp} / \mathrm{Ha})$

$\mathrm{X}_{6}=$ Cost of pesticide $(\mathrm{Rp} / \mathrm{Ha})$

$\mathrm{X}_{7}=$ Cost of shrimp feed (Rp/Ha)

$\beta_{0}, \beta_{1}, \ldots 7$ are parameters to be estimated. $v_{i}$ represent statistical disturbance term and $\mathrm{u}_{\mathrm{i}}$ represent profit inefficiency effect of each farmer.

\section{RESULT AND DISCUSSION}

\section{Rice-fish Farming System}

1) Land Preparation of Rice-fish Farming

Based on the results of interviews with key informants, respondent farmers and field observations, land preparation is done by making a ditch around the width of 1 meter and a depth of 40 to 50 centimeters shown in figure 3 . This Ditch will become a place for shrimp farming. Meanwhile, along with the land preparation activities, the seeds are spread on a plot of land that will be transplanted at around 10-14 days old. The need for rice seeds for one hectare of land is around 24 kilograms.

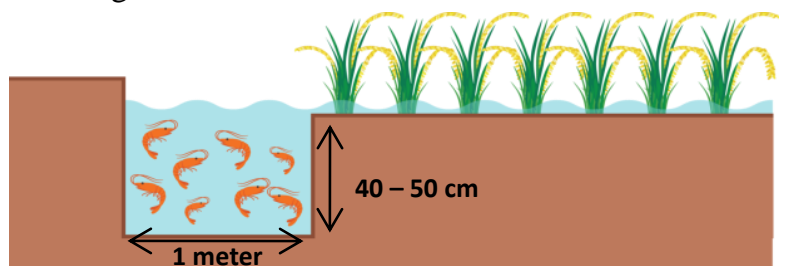

Figure 1. Rice-fish Farming System

Source: This study (2019)

2) Planting Preparation of Rice-fish Farming

The first activity in preparation for planting is plowing land using a tractor. Land plowing is usually done no more than one day. After the soil is plowed, the next activity is fertilizing the soil with urea or organic fertilizer (manure from cow dung) at a dose of 50 kilograms per hectare as basic fertilization. After fertilization, the land is cleared for approximately a week while waiting for roots of seedling that have been sown grow strong.

\section{3) Planting and Shrimp Spreading}

Planting is done after planting preparation is complete and seedlings are approximately 10-14 days old. The planting distance used by farmers varies, but in general, rice-fish farming farmers use a spacing of $25 \times 20$ centimeters. Shrimp seed spreading is done less than 25 days after planting rice. One hectare of land is usually planted with 3-5 reans or 15,000-25,000 vannamei shrimp seeds.

\section{4) Plant Maintenance}

The first fertilization is done when the rice plants are approximately 10days after planting, the fertilizer usually used is urea fertilizer with a combination of SP36 (superphosphate, 36 percent $\mathrm{P}_{2} \mathrm{O}_{5}$ ) fertilizer or TSP (Triple Super Phosphate) fertilizer with a total dose of approximately 200 kilograms per hectare. After the first fertilization, 2 to 3 days do the irrigation and ditch filling with water then spraying using pesticides. A type of pesticide that is normally used in the rice-fish farming 
system is a fungicide. That is because shrimp are vulnerable to death if farmers are not careful in choosing the type of pesticide that is applied. The distribution of shrimp seeds is done no more than one month after planting. Shrimp maintenance is done by giving feed every day as much as 2 to 3 kilograms of shrimp feed per day. The second fertilization is carried out when the rice is 30 to 35 days old using phonska fertilizer or TSP with a total of 200 kilograms per hectare. Fertilization is usually done 2 times after applying basic fertilizer, but if the condition of the rice plants requires additional nutrition, the farmers do fertilization 3 times, the condition is based on the condition of the cultivation crop. Whereas spraying of pesticides is done 2 to 3 days after fertilizing. The application of pesticides is also done based on the condition of the plant, usually done 2 times the application of pesticides in one planting season. Every fertilization and spraying of pesticides around the rice plants are drained on rice planting land and plastic mulchis installed which serves as a fence to minimize contamination of synthetic chemicals against shrimp.

\section{5) Harvesting}

Rice is ready to be harvested at around 100 days, while vannamei shrimp are ready to be harvested for about 60-70 days. In this case, because the spread of shrimp seeds is done approximately one month after the rice plant is planted so that harvesting can be done almost simultaneously. Shrimp will be harvested first after the shrimp harvested and the water has shrunk, 2-3 days after that harvesting is done.

\section{Strengths, Weaknesses, Opportunities, and Threats of Rice-fish Farming System in Lamongan}

Internal and external factors are made through observations at the research location and the results of interviews with farmers and secondary data as supporting data. Table 1. shows that the internal factors that become the strength of rice-fish farming farmers are more dominant than the internal factors which become its weaknesses. This can be seen from the strength factor score (1.9681) which is greater than the weakness factor score (1.0906), it means the strength possessed to develop rice-fish farming is greater than the weakness it has. This will certainly benefit the system if it can continue to strengthen its strengths and minimize weaknesses by increasing productivity and managing appropriately.

The analysis of external factors in table 2 . shows that external factors that provide opportunities for developing rice-fish farming by farmers are superior to external factors that pose a threat. This condition is seen from the sub-total opportunity factor (1.2681) which is greater than the threat factor (1.0474). In other words, the opportunity to develop a rice-fish farming business is more open than the threats that hamper business development (Arsad et $a l ., 2018$ ). This means that the rice-fish farming system has a greater chance of success if relevant parties can manage this system properly. However, threats to the sustainability of rice-fish farming also need to be watched.

Based on the analysis of strategic factors in table 1 .
Table 1. Internal Factors Analysis

\begin{tabular}{|c|c|c|c|c|c|}
\hline \multicolumn{2}{|r|}{ Strategic Factors } & Weight & Rating & Score & $\begin{array}{l}\text { Total of } \\
\text { Score }\end{array}$ \\
\hline \multirow{7}{*}{$\begin{array}{l}\mathrm{S} \\
\mathrm{t} \\
\mathrm{r} \\
\mathrm{e} \\
\mathrm{n} \\
\mathrm{g} \\
\mathrm{t} \\
\mathrm{h} \\
\mathrm{s}\end{array}$} & $\begin{array}{l}\text { Additional income from vannamei } \\
\text { shrimp production }\end{array}$ & 0.0995 & 3.25 & 0.3233 & \multirow{7}{*}{1.9681} \\
\hline & $\begin{array}{c}\text { Vannamei shrimp are easier to } \\
\text { cultivate than other types of } \\
\text { shrimp }\end{array}$ & 0.0867 & 3.75 & 0.3253 & \\
\hline & Shrimp seed are easily obtained & 0.0918 & 4.00 & 0.3673 & \\
\hline & $\begin{array}{l}\text { Shrimp can survive in brackish } \\
\text { water and freshwater }\end{array}$ & 0.0740 & 3.50 & 0.2589 & \\
\hline & $\begin{array}{l}\text { Complementary to minimize } \\
\text { losses in case of crop failure }\end{array}$ & 0.1020 & 3.25 & 0.3316 & \\
\hline & Local government support & 0.0689 & 2.75 & 0.1894 & \\
\hline & $\begin{array}{l}\text { Have a farmer group as a forum } \\
\text { to develop farming }\end{array}$ & 0.0765 & 2.25 & 0.1722 & \\
\hline \multirow{6}{*}{$\begin{array}{l}\text { W } \\
\text { e } \\
\mathrm{a} \\
\mathrm{k} \\
\mathrm{n} \\
\mathrm{e} \\
\mathrm{s} \\
\mathrm{s} \\
\mathrm{e} \\
\mathrm{s}\end{array}$} & Limited business capital & 0.0816 & 2.25 & 0.1837 & \multirow{6}{*}{1.0906} \\
\hline & Shrimp are vulnerable to death & 0.0689 & 3.00 & 0.2066 & \\
\hline & $\begin{array}{l}\text { The quality of rice in rice-fish } \\
\text { farming is lower than the quality } \\
\text { of rice in the monoculture system }\end{array}$ & 0.0408 & 2.75 & 0.1122 & \\
\hline & $\begin{array}{l}\text { Need extra care and water } \\
\text { management }\end{array}$ & 0.0867 & 3.75 & 0.3253 & \\
\hline & $\begin{array}{l}\text { Knowledge and understanding of } \\
\text { cultivation are still traditional and } \\
\text { limited in nature }\end{array}$ & 0.714 & 2.25 & 0.1607 & \\
\hline & $\begin{array}{l}\text { Unprofessional cultivation } \\
\text { management }\end{array}$ & 0.0510 & 2.00 & 0.1020 & \\
\hline & Total & 1.00 & & & \\
\hline
\end{tabular}

Source: This study, 2019.

Table 2. External Factors Analysis

\begin{tabular}{|c|c|c|c|c|c|}
\hline \multicolumn{2}{|r|}{ Strategic Factors } & Weight & Rating & Score & Total of \\
\hline \multirow{5}{*}{$\begin{array}{l}0 \\
p \\
p \\
0 \\
r \\
t \\
u \\
n \\
l \\
t \\
\text { l } \\
e \\
s\end{array}$} & $\begin{array}{l}\text { Vannamei's selling price is } \\
\text { relatively high }\end{array}$ & 0.1250 & 3.25 & 0.4063 & \multirow{5}{*}{1.2681} \\
\hline & $\begin{array}{l}\text { Most farmers have quite a long } \\
\text { experience in rice-fish farming }\end{array}$ & 0.0927 & 2.50 & 0.2319 & \\
\hline & $\begin{array}{l}\text { Market demand for vannamei } \\
\text { shrimp is high }\end{array}$ & 0.1210 & 2.75 & 0.3327 & \\
\hline & $\begin{array}{c}\text { Community service activities } \\
\text { are often carried out by } \\
\text { universities }\end{array}$ & 0.0847 & 0.50 & 0.0423 & \\
\hline & $\begin{array}{l}\text { Promotion of agrotourism and } \\
\text { environmental education }\end{array}$ & 0.0927 & 2.75 & 0.2550 & \\
\hline \multirow{5}{*}{$\begin{array}{l}\mathrm{T} \\
\mathrm{h} \\
\mathrm{r} \\
\mathrm{e} \\
\mathrm{a} \\
\mathrm{t} \\
\mathrm{s}\end{array}$} & $\begin{array}{l}\text { Lack of interest in the younger } \\
\text { generation to work in the } \\
\text { agricultural sector }\end{array}$ & 0.1250 & 2.00 & 0.2500 & \multirow{5}{*}{1.0474} \\
\hline & $\begin{array}{l}\text { Market demands related to the } \\
\text { quality of rice and shrimp that } \\
\text { are free of chemicals }\end{array}$ & 0.0847 & 2.00 & 0.1694 & \\
\hline & Another source income & 0.0806 & 2.50 & 0.2016 & \\
\hline & $\begin{array}{l}\text { The perception of rice-fish } \\
\text { farming that is not suitable for } \\
\text { large-scale farming }\end{array}$ & 0.0766 & 1.75 & 0.1341 & \\
\hline & $\begin{array}{l}\text { weather changes that have an } \\
\text { impact on cultivation activities }\end{array}$ & 0.1169 & 2.50 & 0.2923 & \\
\hline & Total & 1.00 & & & \\
\hline
\end{tabular}

Source: This study, 2019.

and table 2., a grand strategy matrix can be made to 
determine the type of strategy for developing a rice-fish farming business system by farmers as shown in Figure 2. Based on Figure 2. it can be seen that in general, the position of activities rice-fish farming by farmers is in quadrant I which means it is in a good strategic position where the rice-fish farming business has greater opportunities and strengths than weaknesses and threats so that it can take risks aggressively if needed. Besides, the role of related parties is needed to provide socialization, training, and assistance to farmers on how to cultivate rice-fish farming properly to strengthen the existence of rice-fish farming.

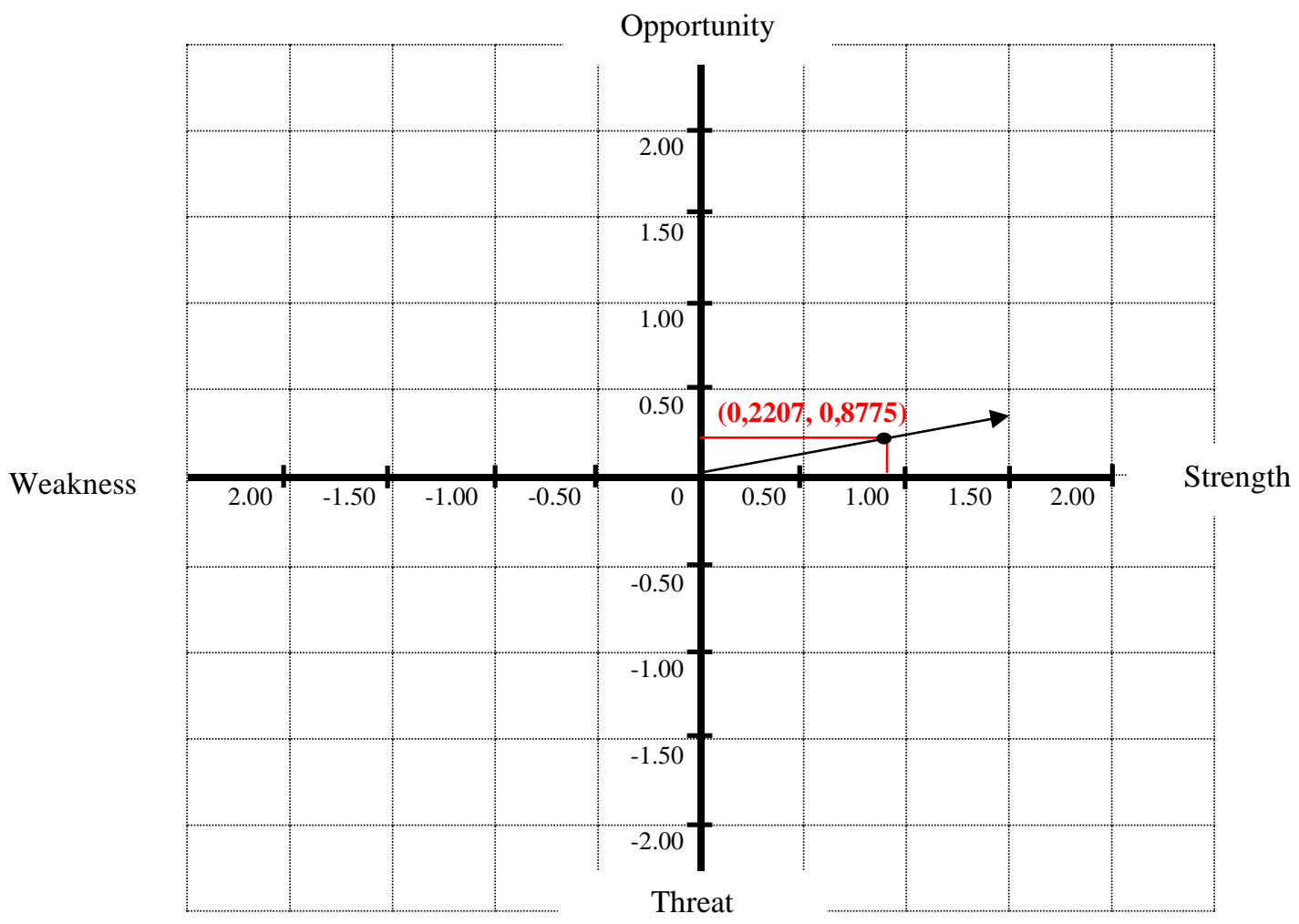

Figure 2. Grand Strategy Matrix of Rice-fish Farming System Source: This study (2019).

Based on the results of the grand strategy matrix we can analyze the S-O, S-T, W-O, and W-T strategies as below:

Table 3. Strategy Analysis

\begin{tabular}{|l|l|l|}
\hline & Strength & Weakness \\
\hline Opportunity & $\begin{array}{l}\text { Increase the production of } \\
\text { rice-fish farming through } \\
\text { support from the government } \\
\text { by distributing products that } \\
\text { support the production of rice- } \\
\text { fish farming. }\end{array}$ & $\begin{array}{l}\text { Related parties provide } \\
\text { socialization, training, and } \\
\text { assistance to farmers on how } \\
\text { to cultivate rice-fish farming } \\
\text { properly. }\end{array}$ \\
\hline Threat & $\begin{array}{l}\text { Policy on marketing rice-fish } \\
\text { farming production and } \\
\text { agricultural insurance to } \\
\text { minimize possible losses. }\end{array}$ & $\begin{array}{l}\text { Demonstrating the cultivation } \\
\text { of rice-fish farming to the } \\
\text { wider community. }\end{array}$ \\
\hline \multicolumn{1}{|l|}{ ing }
\end{tabular}

Source: This study, 2019.

\section{Profit Efficiency of Rice-fish Farming System in Lamongan}

Table 4. shows the effect of each factor of cost production on rice-fish farming using MLE method. Based on the table the value of sigma square is $0.150, \mathrm{H}_{1}$ not rejected because of $\sigma^{2}>0$ and rejects $\mathrm{H}_{0}$ if $\sigma^{2}=0$, which means there is an effect of efficiency in the model because it says there is no effect of efficiency if sigma square is zero. The gamma value indicates a figure of 0.852 indicating that the rice farming activities carried out have not been able to reach 100 percent efficient. The variation of the error term in the model is caused by inefficiency, which is 85.2 percent, while the remaining 14.8 percent is caused by random errors or noise. This is consistent with the theory stating that the gamma value indicates a variation of the composite error value caused by the effect of inefficiency(Battese \& Coelli, 1995). 
Table 4. Results of Estimated Stochastic Frontier Production using the MLE (Maximum Likelihood Estimation) approach

\begin{tabular}{|c|c|c|c|}
\hline \multirow{2}{*}{ Variable } & \multicolumn{3}{|c|}{ MLE (Maximum Likelihood Estimation) } \\
\hline & Coefficient & Standard error & T-value \\
\hline Intercept & 16.01 & 1.002 & $15.96^{*}$ \\
\hline Cost of paddy seed $\left(X_{1}\right)$ & -0.104 & 0.452 & $-23.03^{*}$ \\
\hline Cost of shrimp seed $\left(X_{2}\right)$ & 0.050 & 0.056 & 0.896 \\
\hline Labor wage $\left(\mathrm{X}_{3}\right)$ & 0.508 & 0.560 & 0.090 \\
\hline Cost of organic fertilizer $\left(\mathrm{X}_{4}\right)$ & 0.318 & 0.077 & $4.134^{*}$ \\
\hline Cost of inorganic fertilizer $\left(X_{5}\right)$ & 0.361 & 0.113 & $3.178^{*}$ \\
\hline Cost of pesticide $\left(\mathrm{X}_{6}\right)$ & $-0,240$ & 0.087 & $-2.732^{*}$ \\
\hline Cost of shrimp feed $\left(\mathrm{X}_{7}\right)$ & -0.593 & 0.051 & $-24.54^{*}$ \\
\hline$(\sigma)$ Sigma-square & 0.150 & 0.050 & $2.961^{*}$ \\
\hline Gamma & 0.852 & 0.034 & $24.54^{*}$ \\
\hline Log-likelihood function & -12.26 & & \\
\hline LR test & 31.11 & & \\
\hline
\end{tabular}

Source: This study, 2019.

Factors that significantly affect profit are the cost of paddy seed, cost of organic fertilizer, cost of inorganic fertilizer, cost of pesticide, and cost of shrimp feed. Whereas the cost of shrimp seeds and labor wage has no significant effect on profits. A more detailed discussion of the factors that significantly affect the profit of rice-fish farming based on the estimation results of the stochastic frontier estimation is as follows:

1) Cost of paddy seed $\left(X_{1}\right)$

Cost of paddy seed factors significantly affects the level of confidence of 95 percent. T-test results show that the calculated t-value $(23.03)>t$-value with the degree of freedom of 95 percent (2.256). The variable number of seeds has a negative coefficient of 0.104 , which means that every 1 percent increase in seed costs will reduce rice-fish farming profits by 0.104 percent assuming other input factors are considered constant. The analysis shows that the allocation of the cost of rice seeds must be reduced to get the optimal profit. This is due to the habit of farmers who use large amounts of seeds because there are fears of dead or damaged seedlings (Suharyanto et al., 2015).

2) Cost of shrimp seed $\left(X_{2}\right)$

Cost of shrimp seed has no significant effect on the 95 percent confidence level. T-test results indicate that the calculated t-value $(0.896)<\mathrm{t}$-value with the degree of freedom of 95 percent (2.256), with a positive coefficient of 0.050 . The cost of shrimp seed factor does not significantly affect the profit can be caused by the type and quality of shrimp seeds used by each farmer is the same, and also the density of shrimp seed stocking is the same so that the costs used per unit of land by each farmer tend to be the same.
3) Labor wage $\left(X_{3}\right)$

Labor wage has no significant effect on the 95 percent confidence level. T-test results indicate that the calculated $\mathrm{t}$-value $(0.090)<\mathrm{t}$-value with the degree of freedom of 95 percent (2.256), with a positive coefficient of 0.508 . Based on observations of farmers' demographics that have done by researchers, the workforce used by farmers is wholesale labor per unit of land so that the costs incurred per one hectare of farmers tend to be the same.

4) Cost of organic fertilizer $\left(X_{4}\right)$

The cost of organic fertilizer significantly influences the 95 percent confidence level. T-test results indicate that the value of $t$-value (4.134) > t-value with the degree of freedom of 95 percent (2.256). The cost of organic fertilizer factor has a positive coefficient of 0.318 which means that every 1 percent addition of the cost of organic fertilizer will increase profit by 0.318 percent assuming other input factors are considered constant. This analysis indicates that the allocation of the cost of organic fertilizer still needs to be increased. Rice-fish farmers in the study area generally allocate costs for synthetic fertilizers compared to organic fertilizers, so this causes less than the maximum allocation of costs for organic fertilizer.

5) Cost of inorganic fertilizer $\left(X_{5}\right)$

The cost of inorganic fertilizer significantly influences the 95 percent confidence level. T-test results indicate that the value of t-value (3.178) > t-value with the degree of freedom of 95 percent (2.256). The cost of organic fertilizer factor has a positive coefficient of 0.361 which means that every 1 percent addition of the cost of organic fertilizer will increase profit by 0.361 percent assuming other input factors are considered constant. This analysis indicates that the allocation of the cost of inorganic fertilizer still needs to be increased.

6) Cost of pesticide $\left(X_{6}\right)$

The cost of pesticide significantly influences the 95 percent confidence level. T-test results indicate that the value of t-value (2.732) > t-value with the degree of freedom of 95 percent (2.256). The cost of pesticide factor has a negative coefficient of 0.240 which means that every 1 percent addition of the cost of organic fertilizer will decrease profit by 0.240 percent assuming other input factors are considered constant. Based on the results of the analysis, rice-fish farmers must reduce the allocation of pesticide costs to get optimal profits.

7) Cost of shrimp feed $\left(X_{7}\right)$

The cost of shrimp seed significantly influences the 95 percent confidence level. T-test results indicate that the value of t-value (24.54) > t-value with the degree of freedom of 95 percent (2.256). The cost of pesticide factor has a negative coefficient of 0.593 which means that every 1 percent addition of the cost of organic fertilizer will decrease profit by 0.593 percent assuming other input factors are considered constant. Based on the results of the analysis, rice-fish farmers must reduce the allocation of pesticide costs to get optimal profits.

Hypothesis test in this study used the estimation results of the Likelihood Ratio Test (LR). LR test is conducted to determine whether the respondent farmers have done farming efficiently or inefficiently. The hypothesis used is:

a. $\mathrm{H}_{0}: \sigma^{2}<0$ (no inefficiency effect)

b. $H_{1}: \sigma^{2}>0$ (there is an inefficiency effect) 
The results of the analysis on the frontier showed that the LR test value was 31.11. The LR test value was then compared with the critical value at the 95 percent confidence level (Kodde \& Palm, 1989) in the amount of 2.706. LR test value (31.11)> (2.706), which means $H_{1}$ is not rejected and $\mathrm{H}_{0}$ is rejected, so the value of $\sigma^{2}>0$. Based on these results, it can be concluded that there is an inefficiency/efficiency effect where respondent farmers in Lamongan, East Java, Indonesia have not reached the level of profit efficiency that is 100 percent efficient.

The frontier analysis result shows that each respondent farmer has a different level of profit efficiency. All respondent farmers have not yet reached the 100 percent profit efficiency level. Based on Table 5, the highest profit efficiency of rice-fish farming (maximum) is 0.9706 . This means that the farmers have achieved a profit efficiency of 97.06 percent of the potential profit that can be obtained from the combination of the cost allocation used. The lowest level of profit efficiency (minimum) in rice-fish farming farmers is 0.3700 which means that the respondent farmers only achieve profit efficiency of 37 percent of the potential profit that can be obtained. The average profit efficiency achieved by rice-fish farming farmers in Lamongan, East Java, Indonesia is 0.7805 , which means that the average respondent farmers have achieved profit efficiency of 78.05 percent of the potential products that can be achieved. Profit efficiency results show that there is still a 21.5 percent chance for farmers to increase their profits. This wide variation may be due to low output prices and the imperfect condition of input markets in the study area. The mean efficiency level indicates that there exists room for more profit gain by improving the efficiencies (Sadiq et al., 2015).

Table 5. Minimum, Maximum Value, and Average profit Efficiency of Rice-fish Farming Farmers.

\begin{tabular}{cc}
\hline Value of Profit Efficiency & Profit Efficiency Level \\
\hline Minimum & 0.3700 \\
\hline Maximum & 0.9706 \\
\hline Average & 0.7805 \\
\hline
\end{tabular}

Source: This study, 2019.

\section{CONCLUSIONS}

The rice-fish farming system that is cultivated in Glagah District, Lamongan, East Java, Indonesia is a combination of rice cultivation with vannamei shrimp. The first stage of activities in the rice-fish farming system is land preparation by making a ditch around the width of 1 meter and a depth of 40 to 50 centimeters. Along with these activities is to spread the seeds in a small plot and then planted again at the age of 10-14 days. Paddy seeds needed for one hectare of land are around 24 kilograms, while the need for shrimp seeds per hectare is around 15,000-25,000 seeds. Meanwhile fertilization is usually done 2 times after basic fertilization. Fertilizer used as basic fertilizer is organic fertilizer (manure from cow dung) with a dose of
50 kilograms per hectare, the next fertilization is to use a combination of urea, SP36, and TSP with a dose of 200 kilograms per hectare. Pest and disease control carried out by applying pesticides with a type of fungicide that is done 2 to 3 times. The last activity in this farming system is harvesting, where rice is ready to be harvested about 100 days after planting while vannamei shrimp is around 60 to 70 days.

Scores of strengths and opportunities are higher than weaknesses and threats, where the position of rice-fish farming is in quadrant I, which means it is in a good strategy where this system can take risks aggressively if needed, so the rice-fish farming system will bring benefits if it can be managed properly and increase the income of farmers. Therefore, the role of government and related parties is needed in the development of this farming system to conduct socialization, training, and assistance to farmers.

The input factors which significantly influence profit are the cost of paddy seed, cost of organic fertilizer, cost of inorganic fertilizer, cost of pesticide, and cost of shrimp feed. This might be due to the use of shrimp seedlings and the labor costs of each farmer who tend to be the same in one hectare of land, where labor used by farmers is wholesale labor per unit of land so the costs incurred per one-hectare farmers tend to be the same. While the use of other factors each farmer is different, depending on the skills of each farmer in operating and allocating these factors. Profit efficiency of rice-fish farming in Lamongan, East Java, Indonesia is still not efficient, because it has not reached 100 percent. The average level of profit efficiency of farmers in the rice-fish farming system is 78.05 percent, it means that there are still opportunities for farmers to increase profits derived from this cultivation system by 21.5 percent.

\section{REFERENCES}

Ahmed, N., Zander, K. K., and Garnett, S. T. 2011. Socioeconomic aspects of rice-fish farming in Bangladesh: opportunities, challenges and production efficiency. The Australian Journal of Agricultural and Resource Economics 55:199-219. doi:10.1111/j.14678489.2011.00535.x.

Akbar, A. 2017. The role of Intensifications ff Rice-fish Farming to Increase Rice Farmer's Income Involved in Gampong Gegarang, Jagog Jeget District, Aceh Central, Indonesia. Science \& Agriculture 1(1):28-38.

Arsad, Sulastri et al. (2018). Community Empowerment to Increase Litopeaneus Vannamei Productivity Towards semi-Intensive System by Potential Analysis and selffeed Production. Scientific Journal of Fisheries and Maritime Affairs 4(2): 156-164.

Battese, G. E., and Coelli, T. J. 1995. A model for technical inefficiency effects in a stochastic frontier production function for panel data. Empirical Economics 20(2), 325-332.

Hikmasari, R., Muhaimin, A. W., and Setiawan, B. 2013. Technical Efficiency of Mina Mendong Farm Using Stochastic Production Frontier Approach (Study in Blayu and wajak Village, Wajak District, Malang Regency). Habitat XXIV:2-8. 
Oladimeji, Y. U., and Z. Abdulsalam. 2013. Analysis of Technical Efficiency and Its Determinants among Small Scale Rice Farmers in Patigi Local Government Area of Kwara State, Nigeria. IOSR Journal of Agriculture and Veterinary Science (IOSR-JAVS) 3(3):34-39.

Raharjo, Simon H. T. 2014. Bringing Farmers Communities from Subsistent Scope to Agribusiness Through Agriculture. A workshop on mataram agriculture broadcasts, TVRI. doi: 10.13140/RG.21.1390.6963.

Rahman, M. A. 2016. Integration of Aquaculture with Rice Farming: A Way to Increase Farm Productivity, Food Security, Livelihood Improvement, and Better Environment. 6th International Conference on Agriculture, Kuala Lumpur:Environment and Biological Science, 149-150. doi: https://doi.org/10.15242/IIE.A1216044.
Sadiq, M. S. et al. 2015. Profit Efficiency and Profit Progress among Small Scale Fish Farmers in Niger State, Nigeria: MLE Econometric Profit Frontier Function Approach. International Journal of Aquaculture 5(45):1-12. doi:10.5376/ija.2015.05.0045.

Shefat, S. H. T., Rahman, A., Chowdhury, M. A., \& Uddin, M. N. 2018. Strength, Weakness, Opportunities and Threat Analysis of Integrated Aqua farming in Bangladesh. Acta Scientific Agriculture 2(12):112-116.

Simon, D., \& Benhamou, J. F. 2009. Rice-fish farming in Guinée Forestière-outcome of a rural development project.Field Actions Science Reports, 2:50-53 doi:http://journals.openedition.org/factsreports/225.

Sudiarta, I. M., Syam'un, E., and Syamsuddin, R. 2016. The growth and Production Paddy and Tilapia Production at Legowo Row Planting Sistem. Science \& Technology 16(1),70-80.

Sudradjat and Wedjatmiko. 2010. Shrimp Farming in the pond Field. Penebar Swadaya. 5-48.

Suharyanto et al. 2015. Production and Efficiency Analysis of the integrated Crop Management of Rice in Bali. Research farming24(2):131 
This page is intentionally left blank 